\title{
Entrepreneurial Self-efficacy and Intention: Saudi Perspective
}

\author{
Adlah A. Alessa ${ }^{1}$ \\ ${ }^{1}$ Department of Business Administration, Arab East College, Riyadh, Kingdom of Saudi Arabia \\ Correspondence: Adlah A. Alessa, Department of Business Administration, Arab East College, Riyadh, Kingdom \\ of Saudi Arabia.
}

Received: November 18, 2017 Accepted: January 2, 2018 Online Published: February 26, 2018

doi:10.5539/jms.v8n1p111 URL: https://doi.org/10.5539/jms.v8n1p111

\begin{abstract}
The objective of this study has been to compare motivation, intention, fear of failure and self-efficacy in starting business ventures in Saudi Arabia. Inductive content analysis is used to identify the similarities and differences between two cites and groups of people in Saudi Arabia; both male and female entrepreneurs and those who have already established a business. Furthermore, the paper draws on data gathered from eight interviews in the cities of Riyadh and Jeddah. Four of these interviews were conducted with male entrepreneurs and the remaining four were with female entrepreneurs. A description and analysis of each entrepreneur was developed individually including short observations on the interviewees; noting movements and body language. We found the motivation for being one's own boss is greater in Riyadh than in Jeddah $(\mathrm{p}=0.024)$ whereas self-efficacy is greater in Jeddah yet this difference is not significant. Regarding intention, no significant difference was found between region and gender. Finally, both regions consider fear of failure to be predictable. The study presents important contributions to theorists and practitioners in entrepreneurial activities in Saudi Arabia. Our research has contributed to the study in entrepreneurial motivation, intention, role of management, and role of culture of male and female entrepreneurs in Saudi Arabia hence providing more knowledge and information towards the behavior of Saudi entrepreneurs.
\end{abstract}

Keywords: intention, self-efficacy, novice entrepreneurs, entrepreneurial behaviors, capabilities managing risk, Saudi Arabia

\section{Introduction}

Being an entrepreneur is a career choice and it is very common to have paid employment (Burton et al., 2016; Manso, 2016). Thus, the intention of creating a business is different from the serial entrepreneur's intention to start another business (Simmons et al., 2016). Moreover, it is important to understand the entrepreneurial behaviors and intentions because it plays an important role to the development of the economy and society (Audretsch, 1995; Audretsch \& Fritsch, 2002; Blanchflower et al., 2001; Carree et al., 2002). Thus, entrepreneurial intention is considered to be followed by the action of the entrepreneur (Bird, 1988; Kolvereid, 1996; Krueger \& Brazeal, 1994; Krueger, Reilly, \& Carsrud, 2000). Further research has identified a myriad of reasons that would influence individuals to becoming entrepreneurs such as through experience, background, personal attributes, disposition, trait, and risk taking (Arenius \& Minniti, 2005; Baron, 2004; Shane et al., 2003; McClelland, 1961; Ferreira et al., 2017).

Some research questions have been shaped to achieve the following objectives:

1) What leads the motivation of male entrepreneurs' and female entrepreneurs' to create their own business.

2) Are there any differences in self-efficacy depending on the gender of the entrepreneur.

3) Are there any differences in intention of creating a business depending on gender.

4) Is fear of failure predictable.

\section{Literature Review}

Exposure to entrepreneurship, experience, and the perspectives of self-efficacy are shown in many studies (Zhao et al., 2005; Krueger, 1993; Hsu et al., 2015). Some studies have shown that the more experience individuals have in creating their business the more the entrepreneurial intention, hence the more experience the individual will have in creating more businesses (Dan et al., 2017). Furthermore, the Global Entrepreneurship Monitor (GEM) in the year 2015-2016 found that the highest entrepreneurship participation rate for male and female is 
within the age range of 25-34 and 24-44, while in the United States successful technology business are established by male and female at the age of 29 (Kelley et al., 2016; Wadhwa, 2012). While entrepreneurs in Iran tend to averaging between 25 and 44 years of age (GEM 2014). Yet, female entrepreneurial activities have increased but it seems that these female entrepreneurs are not enjoying appropriate status, however, in developing countries it is shown that female entrepreneurship leads to growth (Rezaei et al., 2017). Above all, the characteristics of entrepreneurial self-efficacy is important to exploring new venture intentions and having strong entrepreneurial intentions while increasing such self-efficacy through training and education (Barbosa et al., 2007; Boyd \& Vozikis, 1994; Zhao et al., 2005; Bird, 1988; Florin et al., 2007; Mueller \& Goic, 2003). McShane \& Von Glinow (2003) mention that self-efficacy is "a person's belief that he or she has the ability, motivation, and resources to complete a task successfully" in which it is an important factor for entrepreneurial competencies and business opportunities (Schneider, 2017).

Moreover, Bandura \& Chen et al. $(1977,2004)$ state that self-efficacy depends on the belief of individuals and their capabilities to accomplish a business. Self-efficacy demonstrates individual's behavior and plays a role on the choice made by individuals, and the level of effort and perseverance. However, an individual with low self-efficacy will not pursue and persist a specific task compared to those with high a self-efficacy (Bandura, 1997). According to Rezaei et al. (2017) an entrepreneurial passion has a strong influence on entrepreneurial self-efficacy. Schumpeter (1934) Carland, Hoy, Boulton, \& Carland (1984) suggest a conceptual framework that differentiates small business owners from entrepreneurs. A focal factor in differentiating entrepreneurs from non-entrepreneurs for this framework is pro-innovation behavior. Contrary to many studies, Gartner (1985) states that there are differences between non-entrepreneurs and entrepreneurs as well as differences between entrepreneurs themselves. Studies conducted by Silva, Gomes, \& Correia (2009) show that Brazilian entrepreneurs take higher risks than Portuguese entrepreneurs do whereby managing risk is a trait for successful entrepreneurs (Botha \& Robertson, 2014). Furthermore, there is a relationship in the motivations of individuals in creating their own business and economy, challenge market, opportunities, and self-actualization (Schumpeter, 2002; Shane \& Venkataraman, 2000; Kautonen \& Palmroos, 2010) in which the success of entrepreneurs is a complex phenomenon determined by some factors such as the economy and socio-culture (Piacentini, 2013).

Culture, gender, ethnicity, and religion are other factors that further have significant impact on motivation (Shane et al., 1991). In the United States, for instance, less female compared to male start their own businesses (Reynolds et al., 2004). In contrast, according to GEM data in 2014, Brazilian females own 51 per cent of the businesses in their country. Indeed, being your own boss depends on individuals' personality, intensity, social, and contextual motivation (Valencia, Restrepo, \& Restrepo, 2014). However, such motivations lead individuals to not only plan and achieve goals but also lead them to develop a unique business plan (Sivarajah \& Achchuthan, 2013; Carvalho, 2009; Testa \& Frascheri, 2015). Furthermore, Santos \& Silva (2012) consider the business plan as guidance for entrepreneurs to manage their work by adapting different models for a different business. Some scholars have agreed that business plans are important to have a successful business where others questioned this fact (Gruber, 2007). Thus, some scholars convey that in order to have a better understanding of entrepreneurship and entrepreneurial intention more attention must be given to causes and conditions (Valliere, 2015).

Furthermore, researchers have stated that there are eight outcomes to motivate the intention of entrepreneurs. They include: "freedom to work your own methods, feelings of accomplishment, intellectual stimulation, performing a wide variety of activities, being respected by others, having opportunity for advancement, being rewarded for performances, and working with congenial associates" (Kuckertz \& Wagner, 2010). Gartner's (1989) attention is primarily focused on the phenomenon of the creation of individuals' new businesses as well as the steps of creating their own business. On one hand, some researchers differ in opinion such as Bhave (1994) who believes that the focal process activities include "opportunity recognition, development of the business concept, production technology, organizational creation, and the product technology itself". On the other, Shook et al. (2003) expand opportunity recognition to consist of segmented projects for exploration and discovery while deciding to "exploit" the opportunity simultaneously.

\section{Methodology}

\subsection{Data Collection}

Data for the paper have been collected in two phases. First, information was obtained through formal and informal interviews depending on the occasion with 8 male and female Saudi entrepreneurs in Riyadh and Jeddah city. In the second phase, extra information was obtained through phone calls for either clarifying some answers or including extra information that would help for this paper. Eight organizations from different types of businesses agreed to participate in the study and had been provided information regarding the questions they will 
be asked. Furthermore, this paper is a case study is based by following Yin's (1994) three phase protocol guideline.

The first phase is used by initiating developed research questions that the study focused on. Next, multiple cases were selected to be interviewed, while using the instruments in the data collecting method of which are qualitative and quantitative data. Moreover, this paper also uses flexible methods in collecting the data. Using case studies give in depth understandings of Saudis behind male and female concepts in becoming entrepreneurs. The interviews were formal and informal, depending on the case itself and the ages of the entrepreneurs by which due to the country's culture, we practiced formal interviews with particular male and female entrepreneurs. The data collection locations were in two locations; first the capital city of Saudi Arabia, Riyadh, and the second location in Jeddah. The reasons for choosing these two locations were made because Riyadh is the capital city and the second location, Jeddah, is a more liberal city where people have different mentalities and perceptions from those in Riyadh. In this paper the use of case study is to investigate contemporary phenomenon in real life context of Saudi entrepreneurs' and some observations will be done as the requirement for analyzing case study (Yin, 1994).

\subsection{Participants}

The selected population for this paper involved Saudi male and female entrepreneurs in general with no focus on specific areas of interest. Moreover, the researcher concentrated on entrepreneurs to examine their potentials toward their intention and self-efficacy and leaving their employment job to creating their own business. At the time of data collection for this research in June 2016 to November 2016, the total number of interviewed entrepreneurs in different types of business owned was 8. Indeed, the participants were randomly selected ignoring age, education degree and size of their venture. In addition, in this research the focus is only on entrepreneurs, excluding any Novice Entrepreneurs because their self-efficacy and intention vary from entrepreneurs who have experience for at least ten years in business making their perception and knowledge different. Additionally, the aim of the interview was to deeply investigate the reasons of entrepreneurs' self-efficacy and intention towards creating their own business. Moreover, time is considered very carefully for both entrepreneurs' and researcher in order to have effective and efficient data. Each entrepreneur was promised to be anonymous. Some entrepreneurs asked to have the questions sent to them by email, however, the researcher convinced the entrepreneurs to do conduct the interview face to face by explaining to them the meaning of case study and the purpose of obtaining more information. In addition, this paper focused on choosing entrepreneurs who created their businesses from the period 2006 to 2012 due to the Saudi culture experiencing great changes during this period while opportunities for female entrepreneurs opened up significantly.

\subsection{Research Design}

The entrepreneurs voluntarily participated in this research and the researcher went to the business location of each entrepreneur. The questions were structured and unstructured depending on the interview. In fact, the researcher tried best to ask unified questions to all participants in which in some cases the researcher contacted some entrepreneurs asking a missing question and explaining to them the reasons for contacting. Entrepreneurs were asked to provide demographic information such as age, gender, education, age of their business and previous business experience (Bagheri et al., 2017) which according to Yin (2009), using case study design is considered a major strength.

It is challenging to design a case study research project that can be effectively and aptly answered while collecting data can be tedious time work often leading to mammoths' amount of data (Yin, 2009; Cavaye, 1996). In addition, Eisenhardt (1989) points out that research design allows the researcher to have an advantage in adopting and adapting research methods that clarify the phenomena being investigated.

\subsection{Data Analysis and Result}

An exploratory interview was carried out in this paper to give an in depth understanding of male and female entrepreneurs' self-efficacy, intention, and motivation behind the creation of their businesses in Saudi Arabia. Yin (1994) point out that it is difficult to analyze case study evidence because the variation of the data collected in which eight cases were successfully interviewed with rich data and the software used in this analysis QDA analysis Miner.

\section{Cases from Riyadh City}

\subsection{Case One}

Case one is a 55 year old male from Riyadh who owns and operates a business in a marketing company. He started his business twenty years ago where he was brought up by a destitute family. He did not complete his 
education even though most of the education in Saudi Arabia is free of charge, yet from his point of view "...The life at that time was so harsh, there were no chance of me finishing my education... in fact I was carless about my education I felt sorry when my life passed in front of my eyes without completing my education. I realized this between the ages 23-24 when I saw one of my old friends holding an executive position then decided to do something but I could not figure out what or how and why... Years after starting my own career I realized one must be strong enough in all aspects of business in terms of being a manager and a decision maker. The fear of losing your business or taking the risk can be unpredictable at any time... " His responsibilities of support and care towards his family and his self-confidence are what drove him to become an entrepreneur. Case one claims that opportunities are not important in creating a business since opportunity is always present. He operates three branches of his business in different cities in the Middle East where he indicated that once individuals have successfully operated the first business then there will be little difficulty establishing the same type of business in the same field. However, such an operation requires a specific budget and a lot of patience and rationality in choosing the location of the second and third businesses. Above all, having flexible timings will allow him to be more productive since he has more than one branch for his company.

He further pointed out that people are different from one city to the other therefore it is essential for one to be conscious of cultural differences in order to succeed in one's business. Case one has worked in many places but each time he either resigned or was expelled from work. Afterwards, case one started to think about creating his own business in his 30 s when there was a high demand for marketing at the time in Saudi Arabia. Not only is case one motivated to start his own business to show he has strong self-efficacy but also what motivated him was his desire to be his own business man to prove he could lead success rather than merely being ordered by a superior. He states that: "...Thinking of returning to work for someone else is painful. I cannot handle it; I cannot take orders from other people ..." Not only is case one motivated by being his own boss rather than being ordered by others but also by his passion and excitement of establishing a business.

Case one asserts that mamagment is very imoprtant for every business in which personality traits would ultimately lead to weak management or strong mangemt resulting in the quality of service provided to customers. Development in the country has provided many oppurtunities for both male and female entrepreneurs where females practice without limitation except for a few that require male to handle specific types of jobs. We observe that case one is active in both personality and lifestyle. He is very vigourous and energetic, always smiling and never hesititaing when answering the question being asked. Case one is confident and optimistic.

\subsection{Case Two}

A 60 year old male, from Riyadh runs a business in a consultant law office. After he graduated from a bachelor's degree he aimed to be an academic by furthering his education to take the masters and doctoral degrees. Case two worked at a well-known University in the first ten years of his career. He stated that "... My first client was male and was hesitating to give me his case in the beginning because my office was new...after long conversations and discussion between him and I, he eventually felt comfortable dealing with me...we won the case ... this was my first time court pleading..." Moreover, he developed the intention of creating a business to have flexibility in his hours of worktime. Case two is motivated by the fact that his type of business was unique at the time of when it was established and his independence has helped him flourish.

Moreover, case two mentioned that people have many different reasons behind creating their businesses in Saudi Arabia, for instance, for not only helping the community but also to gaining financial assets and taking advantage of the experience of being one's own boss. Being a perfect manager may influence both male and female in terms of starting an individual business while the perception of family may also effect the decision especially on females in which many males believe that they are the breadwinner and female are not responsible for sharing the expense of home duty. However, nowadays male and female do not follow such beliefs anymore due to many changes in the society that has taken place in the last ten years.

Case two believes that if one is preoccupied with events outside the business then the enterprise will fail; one must always be diligent and studious. The fear of losing the business keeps him constantly aware and cautious, not relying on "temporary" managers, to avoid eventual demise. Unquestionably, the desire to become your own boss is a demand for male and female but the lack of motivations and intentions behind the business prevent people from taking steps ahead. Individuals must have target, plan, and patience to create a successful business venture. Case two emphasis that knowing the risk of your business is of focal importance while business failure is not as important to him since his business is a continues process that many people demand for. In the worst scenario, case two plans on teaching law rather than dig deep into an unsuccessful business. We observed that he was very talkative and not quite personal at all. 


\subsection{Case Three}

A 43 year old female from Riyadh owns a gas station joint business with her husband. She invested in her husband's business 10 years ago when she was around 33 years old. In addition, her husband also owns other businesses in different fields as well. Case three states that: “... It is no shame or harm for women to own gas stations...people are always asking me how come a woman owns such a business... our culture and customs look at it from different perspectives...my major is in business management and I am aware of all the advantages and disadvantages of taking the risk of managing time and the business...knowing the risk management of any kind of business is important because you are investing in it and you do not want to lose any money" she was very successful at school and gained a bachelor's degree in business management. At that time, the economy was booming and many individuals were encouraged to creating their own unique business. Moreover, with her budget she decided to become a shareholder in one of her husband's businesses. Not surprisingly, she did not quit her job in the government since a lot of females have their own businesses as well as work either in public or private companies. It shows that the motivation for case three to join the business sector was to learn how to be her own boss. The tedious effort of starting a business was reduced since her business had already been established and she need only to manage the whole enterprise as she has a strong personality. Case three's motivation was to first gain experience then move off track into starting a different kind of business using her own money to which she has stated that "... I had a special vision that one day I will be one of the richest women in the word... and will be very well known ..."

She desires to have flexibility with hours to spend the time with her children and have time for herself while being active in the community for personal desire and achievement. Most of her friends thought there was something wrong with her choosing a gas station as her business since most consider it for the masculine male and not the feminine. Upon asking her questions about the business, her friends developed an interest to such an enterprise. Case three considers it predictable to know whether individuals will lose their business or maintain it. For instance, if clients' needs are not understood and service is not of prime quality then this would ultimately lead to business failure. In the worst scenario, case three will return to her old job to avoid losing anything drastically. We observe that case three sometimes smiles broadly and sometimes did not smile at all depending on the question asked. In addition, she kept her hands closed and crossed throughout the interview. We found that case three was very polite and she delivered her words and answers carefully to the questions asked.

\subsection{Case Four}

A 37 year old female from Riyadh owns an art studio. She had excelled and been studious in art since she was a child. "It is important to have passion for everything you do" case four starts her sentences in such a manner. She is very talented and her parents had been encouraging her until she graduated to pursue the career she desires, yet she had no luck of obtaining a job with her lack of experience. Case four started to seriously search on how to become an entrepreneur by asking experienced friends whose parents own businesses, asking for advice. Yet, she needed more knowledge in order to start her business which gradually came over the years. Success was between her eyes and she would never accept any sort of failure in her career. Furthermore, case four is made special by her unique business that is not commonly available. She rented a studio and started teaching art to children. It was a big challenge for case four to start this but over time she became well known and rented larger places when her reputation spread amongst families. Her focal intention when she started her business was to be independent with free working hours. Case four has great ambitions and dreams with a myriad of ideas she wanted to put into practice as well as commitments to goodwill, reputation and activity in the community.

To enter a new career one must have a clear vision and different personality trait in order to accomplish one's target and to be a successful manger. Thus, the characteristics of individuals embark on the success of the business. Although it may seem otherwise, self-efficacy is a strong motivation for case four in which she mentioned that without self-efficacy and with a lack of belief in oneself one could not accomplish anything. She was convinced in the early stages of her career that once people learned of her reputation and her studio profits would come. Furthermore, she holds that "women hold up half the world" conveying that females can deal with many issues presented in the business industry but their ambitions only crushed by their surroundings. We observed that case four talks about her-self a lot; telling us how she became well known in a short period of time, how many interviews she had attended on television and three art gallery she had coordinated since she started the business. Furthermore, she reveals a lot of body language with continuous movement. Throughout the interview she cracked he fingers and played with her nails. Later, she got occupied by the children who kept knocking at her door asking when the lesson will start. 


\section{Cases from Jeddah City}

\subsection{Case Five}

A 65 year old male, from Jeddah, owns a Construction Company. He started his business 35 years ago and is now considered one of the leading companies in Saudi Arabia. He finished primary and intermediate school when his father decided to let him quit school to work with him. He stated that "I cannot imagine myself working for someone else ...I always see people working for my father and since then I wanted people to work for me.... I like to give orders not to receive them... and business requires for an excellent manager. Without a high skill of management the business would cease to exist... " By that time, he started helping his father in finance in which his job focused on revising their customers' bills.

It was very hard for him to start this way but later on, with his father's help, he accepted the work and became faster in auditing the invoices. As a whole, case five showed considerable goodwill and his attitude was normal in terms of body language in which there were almost no movements at all. Accordingly, case five was preparing his company brochures, newspaper, and some contracts to show us the capabilities of his company.

Upon asking case five a question on his intentions behind creating his business he immediately replied saying: "I could never take any orders from anyone except my father... my father had more than fifty workers why would I leave him and work for others... right now we have more than four thousand employees ...plus, he we always had a flexibly in time; we could either go to work or stay home it is our choice...". In addition, this is the only field in which case five can be creative in since has no other experience in any other field. This shows that his motivation is to keep the family business that had been present since he was a child running. Furthermore, he states that: "a fortune was already established from my father, this gave me self-confidence in that I would not lose anything If I gave it a shot...later on self-efficacy drove me to be invigorative. I never feel like I am working with my father, I feel as though the whole business is mine..." Furthermore, the liabilities and risks of losing one's venture is possible for all kinds of businesses whether the business is small or large because mistakes are cumulative over time or the economy of the country leads to a demise of any chance of success. We observe that at times, case five, was talking in glory about how his company came to be one of the most well know companies in the country. Arrogance was very evident on his face; yet, he was polite and patient and welcomed us for any further questions that could help our society.

\subsection{Case Six}

A 41 year old male from Jeddah, owns a restaurant in chain partnership with his cousins. After the death of his father he inherited all the money. Upon graduating from university he started to look after his money and took a role in the restaurant chain. He mentioned that: "I knew I would do good in business, as I always see my family doing business... they own very large companies ... but my mission had been to finish my education first then think about what may come after ..." At the beginning of the interview, he refused to answer some questions because he considered it private, but when asked the same question in an alternate way he answered without any notice or hesitation. He later stated that to him "all businesses are competitive which requires individuals who have the capabilities, responsibilities, and willingness to take the risk of either losing the investment or not." Case six's motivation emerged from the opportunity to keep the family business running and the opportunity of free working hours. There is a high degree of competition in the Middle East that is concentrated with restaurants compared to countries in other parts of the world. Nevertheless, he showed no intention of operating any other type of business.

Self-efficacy is different from person to person depending on the extent of their self-confidence and experiences from previous work or family businesses; such a trait is important to have notable ventures. Moreover, with greater confidence and self-efficacy the individual would be able to handle and manage any kind of business with hard work and strenuous effort. The personality trait of managers is essential to running the business generally and its complications specifically. If the manger fails to responsibly and diligently carry out the task, there is the high possibility of losing control of employees and ultimately the company itself. Therefore, personality trait is needed in order to operate a successful career. In addition, case six believes the possibility of failure is not an option with a history of family businesses in which losing one branch of business will not affect the other businesses. From a financial perspective, although different branches of a business provide greater income, the budget, employees, and costs are ultimately accumulated. We observe that case six was gentle while talking and was very friendly with the interviewers. In addition, he had an answer for every questions asked while conveying normal body language. 


\subsection{Case Seven}

A 45 year old female from Jeddah owns and operates a gym business for 8 years. She has a master's degree in language and translation in which she stated that "my major helped me a lot in my business that required me to travel a lot in order to purchase machines as well clothes to sell in my gym... knowing more than one language is important to communicate with the rest of the world..." Nowadays many similar businesses exist compared to that of the last five years in which she views it a big challenge to sustain your own business in a highly competitive market. In addition, her parents and brothers had supported her during the creation of her career. The main reason behind starting the business was to cover her financial expenses. Her ability to accomplish different tasks simultaneously allows her to stand out as a woman in the business sector. Moreover, it is important for the country to provide opportunities to prospective businessmen and women to obtain a competitive environment. Management skills are highly important otherwise the business will demise in a field that is concentrated.

Moreover, case seven is required to travel a lot and meet many other business women to learn about the reasons behind their own business establishments. Her intention in being an entrepreneur is to be an independent female convey there is no difference in the capabilities between male and female when starting a business. We observe case seven is very fashionable and generous with full make up on. During the interview, she did not smile; looking greatly stressed. She was neither patient nor friendly and at times she seemed hesitant in her answers. She was speaking briefly and pointedly. In terms of body language; she had no movement at all.

\subsection{Case Eight}

A 58 year old female from Jeddah owns a plastic manufacturing company; a highly unique business for a female entrepreneur. Case eight studied her bachelor's degree in a private university where she wished to have her own business in order to cover the expenses as well to work independently from others. Her intention of creating a business was to be independent from her family. Case eight was asked about the relationship between the culture of the country and the ability to establish ones business in Saudi Arabia to which she responded "The culture of Saudi Arabia is similar to that of any culture; it has regulations and roles that need to be followed.... the key thing is what you put in your mind... you are the one who either makes things simple or complicated; just live the life as it is..." As case eight stated: "If I did not own this kind of enterprise I would not succeed in any other field because such a business is not widely available... my life is simple since this kind of business does no face many threats from the few competitors there are..." she ended her answer by claiming that creating an individual business has nothing to do with culture but with customs within a country. Case eight was asked about the relationship between the culture of the country and the ability to create a business in Saudi Arabia to which she responded "The culture of Saudi Arabia similar to that of any culture in a country, it has regulations and roles that need to be followed... the important thing is what you put in your mind... you are the one who either complicate or simplify issues..."

Across the globe, female entrepreneurship plays an important role on the growth of the economy, yet male are more likely to become entrepreneurs than their counterparts (Kelley et al., 2015). Self-efficacy was important to case eight in her strive to obtain self-fulfillment and independence. Good management needs good leadership skills to avoid making mistakes that could lead to business failure. We observe that case eight was very quiet while talking and was barely audible from the loud voices of her workers and the machines that were running. Her answers were very redundant giving us the impression that she is very friendly, invigorative and confident.

\section{Results}

\subsection{Data Analysis}

\subsubsection{Entrepreneurial Motivation}

Among the full sample of 8 cases with four male and four female entrepreneurs'; table 1 provides the description of the characteristic of Male and Female Entrepreneurs.

\subsubsection{Result}

The results show that the surromding enviroment of female consists of encouragement from family, friends and the community to contribute to motivation to being an entreprenuer. In addition, some cases look at the creation of business as confined to men since their personalities are dogmatic and tough compared to their counterpart. 
Table 1. Characteristic of male and female entrepreneurs

\begin{tabular}{lllll}
\hline Case & Gender & City & Age & Sector \\
\hline Case One & Male & Riyadh & 55 & Marketing Company \\
Case Tow & Male & Riyadh & 60 & Consulting Law Office \\
Case Three & Female & Riyadh & 43 & Gas Station \\
Case Four & Female & Riyadh & 37 & Art Studio \\
Case Five & Male & Jeddah & 65 & Construction Venture \\
Case Six & Male & Jeddah & 41 & Restaurant Chain \\
Case Seven & Female & Jeddah & 45 & Gym for Female \\
Case Eight & Female & Jeddah & 58 & plastic manufacture \\
\hline
\end{tabular}

The subjects under study were 8 male and female entrepreneurs from two different regions in Saudi Arabia. They were chosen randomly but specifically in the period of when the business was created between the year of 2004 and 2017 to make certain the range of entrepreneurs are similar in terms of the regulation of the country and the system in which their ages range 37-65. The results indicate that in general, the rate of male and female entrepreneur's motivation and intention for creating their own businesses are slightly similar. However, some other factors (e.g., family business, cover expenses) do have influence on male and female entrepreneurs. This study also tackles different angles which identifies the influence on both male and female who own business management and the possibilities of losing individuals business. Furthermore, these results first compare male to female then among region to note the motivation and intention to starting their own businesses.

In this paper, we found that the personality of entrepreneurs and their traits can lead to some male and female entrepreneurs to start their own business with no difficulty. Ultimately; "skills, knowledge and abilities are reasons for women to get involved in entrepreneurial activities, beside their willingness to do positive things" (Kumar et al., 2012).

Table 2. Motivation of male and female entrepreneurs by region

\begin{tabular}{lllll}
\hline Variable- motivation & Riyadh & Jeddah & F-test & P-value \\
\hline Own boss & $9.4 \%$ & $0.0 \%$ & 9.000 & 0.024 \\
Self-efficacy & $3.1 \%$ & $9.4 \%$ & 2.000 & 0.207 \\
Family business & $0.0 \%$ & $3.1 \%$ & 1.000 & 0.356 \\
\hline
\end{tabular}

Table 2 shows the percentage of male and female entrepreneurs between regions and their opinions regarding motivation. The results convey that in terms of region; Riyadh entrepreneurs have a 9.4 percent reason behind the creation of businesses in order to be their own bosses while it also shows the p-value is significant at 0.024 amongst the sample in Riyadh, this demonstrates that factor analysis for being one's own boss in Riyadh city is appropriate. When comparing two different regions, the ratio of variance of F-test was 9.000 for motivation to be their own boss in which 10 per cent is the significance level. In contrast, Jeddah entrepreneurs have a 9.4 percent motivation that is turned to self-efficacy. In which, in two cases it seems that their motivation is to keep their family business running. Surprisingly, there were no significant differences observed in self-efficacy and family business (Table 2). Moreover, QDAs were continually conducted to compare the differences among various variables that were tested in this study such as case two in Riyadh who also wants to be involved in the community significant at 0.024 . While case eight in Jeddah seeks more development in his career significant at 0.022. In addition, case four's passion drove her to start a business at no significance of 0.356 . Furthermore, the chi-square for both regions for own boss is 4.800 , while chi-square for self-efficacy was 2.000 ; however the chi-square for family business was 1.143 .

Moreover, in terms of the influence of management in creating the entrepreneurs own business two variables were tested. Most case results show that in Riyadh city 6.3 percent believe entrepreneurs must have a strong ability in controlling their business as well as with their employees. While Jeddah has a greater percentage of 9.4 percent in which both regions convey no significant p-value. In addition, male and female entrepreneurs were asked about the fear of business failure in which both regions assume fear of failure is predictable at 9.4 percent and unpredictable at 3.1 percent.

\subsubsection{Entrepreneurial Intentions}

The variables below examined male and female entrepreneurs toward the aims behind creating their enterprise in which some started a business plan ahead of time while others did not have any business plan until after getting 
involved in their family business.

Table 3. Intention of male and female entrepreneurs by region

\begin{tabular}{lllll}
\hline Variable- intention & Riyadh & Jeddah & F-test & P-value \\
\hline Independency & $0.0 \%$ & $6.3 \%$ & 3.000 & 0.134 \\
Flexibility with hours & $12.5 \%$ & $6.3 \%$ & 3.000 & 0.134 \\
\hline
\end{tabular}

Table 3 shows that male and female intention has no great significance. Furthermore, compared to Jeddah, Riyadh entrepreneurs have greater intention for more flexibility in working hours with the freedom of coming in and out of work. Comparing the motivation between male and female, table 4 bellow shows that male are motivated to be their own bosses at 3.1 percent while female at 6.3; this demonstrates that females have a higher tendency to be their own boss. However, it shows no significance in the p-value at 0.537 while the chi-square for the variable independency and flexibility with hours is 2.667 .

Table 4. Motivation of male and female entrepreneurs by gender

\begin{tabular}{lllll}
\hline Variable- motivation & Male & Female & F-test & P-value \\
\hline Own boss & $3.1 \%$ & $6.3 \%$ & 0.429 & 0.537 \\
Self-efficacy & $6.3 \%$ & $6.3 \%$ & - & - \\
Family business & $3.1 \%$ & $0.0 \%$ & 1.000 & 0.536 \\
\hline
\end{tabular}

In terms of self-efficacy, male and female entrepreneurs are equal at 6.3 percent and thus not significant. In contrast, the sample shows 3.1 percent of male come from family businesses and 0.0 percent of female come from family business. Moreover, table 5 shows that the intention of female entrepreneurs in Jeddah desire to be independent and flexible with working hours at 6.3 percent while male entrepreneurs in Riyadh seek flexibility in timing at 12.5 percent.

In addition, when comparing variable differences between gender influences on management, two variables were tested based on case answers in which the result shows that 6.3 percent of male entrepreneurs believe one must constantly be diligent while 9.4 percent of females believe that business diligence is highly important. Regarding personality trait, compared to 3.1 percent of females who hold that personality plays a key role in management, 6.3 percent of male hold this as focally important. In two cases, 6.3 percent of male hold that fear of business failure is predictable while in another two cases, 6.3 percent claim the business failure is unpredictable. In contrast, all female entrepreneurs' results show that fear of failure is predictable at 12.5 percent.

Table 5. Intention of male and female entrepreneurs by region

\begin{tabular}{lllll}
\hline Variable- intention & Riyadh & Jeddah & F-test & P-value \\
\hline Independency & $0.0 \%$ & $6.3 \%$ & 3.000 & 0.134 \\
Flexibility with hours & $12.5 \%$ & $6.3 \%$ & 3.000 & 0.134 \\
\hline
\end{tabular}

Code frequency is shown in table 6 demonstrating the number of times the code appeared in the cases. Table 6 shows 3 entrepreneurs were motivated to be their own bosses at 37.5 percent and 4 entrepreneurs at 50 percent were motivated by self-efficacy while 1 entrepreneur at 12.5 percent came from family business.

Table 6. Motivation code frequency of male and female entrepreneurs

\begin{tabular}{lll}
\hline Motivation & Cases & $\%$ Cases \\
\hline Own boss & 3 & $37.5 \%$ \\
Self-efficacy & 4 & $50.0 \%$ \\
Family business & 1 & $12.5 \%$ \\
\hline
\end{tabular}

In addition, the frequency for intention is shown in table 7. Two entrepreneurs intend to be independent at 6.3 percent while six entrepreneurs intend to have a flexible working schedule at 18.8 percent. Indeed, this paper demonstrates that the role of management is highly important in decision making for all aspects of business. The 
result shows that male have more opportunities than females in starting a business whereby one case noted that opportunities are always present. The result shows that owning a family business reduces the chance of losing the business, as case four indicated, due to the size of the business and its reputation.

Table 7. Intention code frequency of male and female entrepreneurs

\begin{tabular}{lll}
\hline Intention & Cases & Cases \% \\
\hline Independency & 2 & $6.3 \%$ \\
Flexibility with hours & 6 & $18.8 \%$ \\
\hline
\end{tabular}

\section{Discussion}

Several studies have explored the factors that motivate people to become entrepreneurs and the influence on their intentions of becoming entrepreneurs. Indeed, this paper did find an interesting fact about the reality of male and female entrepreneurs in Saudi Arabia. Furthermore, this study looked at some of the same factors that motivate people and their intentions to become entrepreneurs.

Case one assumed that an opportunity is not important to create a business since opportunity is always present. In contrast, Minniti \& Nardone (2007) assert that opportunities are considered an important factor that influence the activities of entrepreneurs'.

Brusch (1992) demonstrates that male entrepures are more sucessful in terms of conventional economic performance than female entrepures. However, case one cerrtifies that one would desire to earn a lot of income. On the other hand, fear of failure is considered an important obstacle faced by male and female entrepreneurs since starting the business, even when an opportunity is identified (Foo, 2011; Welpe et al., 2012). Some scholars agree that risk management is ingrained in all business ventures (Beck, 1992). The risk of failure is a reality that is faced among all entrepreneurial companies. Churchill \& Merry (2017) conducted a study showing that during the first five years, 50 percent of the time, small enterprises fail for a myriad of reasons including poor business plan, lack of entrepreneurial capacity, and poor macroeconomic conditions.

Manolova et al. (2012) hold that each community has difrrent independent motivations. The result shows that the enviroment surronding females include encouragement from family, friends and the community which are ultimately factores that motive indiviual to be an entrprepure- In addition, some cases view the creation of business as confined to only men since their personalities are dogmatic and tough compared to their counterpart. Hofstede (1991) asserts that females are less assertive, tough, and focused on material success. However, gender roles are a fact in Saudi Arabian culture due to families being very conservative and attached to their cultures and traditions.

The culture of Saudi Arabia may influence the entrepreneurial activity of females (Ritchie \& Brindley, 2005). Moreover, Zolin \& Watson (2012) argue that female entrepreneurs have been capable of managing their personal lives with work while still generating an income. In addition, case six stated that "women hold up half the world" whereby females can deal with many issues in the business yet their ambitions crushed by their surroundings. Thus, female entrepreneurs goals are demised and valued competition and contribution are weakened (Hans, 2017). Undoubtedly, this paper shows that the role of management is very important in speed decision making for all matters related to the business individuals have to deal with. Indeed, the society has a great influence on both genders in general but on females specifically. However, one study conveys that female entrepreneurs can be stronger entrepreneurs if they completely avoid risk, flexibility and autonomy compared to their counterparts (Adachi \& Takanori, 2017).

The motivation for case six was to keep the family business running and to grow more investment since opportunity was available. In the United Kingdom, more male entrepreneurs start up their ventures compared to their counterparts (Burns, 2011). Indeed, some people in Middle East conduct traditional business and do not encounter high degrees of competition. Ostensibly, the result showed that male and female entrepreneurs are motivated by inaugurating their ventures through opportunities. In contrast, Greene et al. (2003) asserts that motivation for women to start their business comes from themselves and is not reliant on the country from which they come from. The aspirations and intentions for case six's business tis o show her ability and prove there is no different between male and females in the creation of a business. The Americans have different cultures, values, and religions from Europeans just as countries within in the Middle East do. Moreover, culture plays an important role in states of all countries, however, nowadays everything is changing where people have greater access to media and became more educated. Furthermore, Mueller \& Thomas (2000) sugest that culture 
influences the development of particular personality traits and motivates social engagement that is not present in different societies. However, Cacciotti \& Hayton (2015) argue that fear of failure can result from personality or behavioral trait whether in a stable or threatening environment.

Furthermore, in general, researchers agree that culture is "a shared and learned world of experiences, meanings, values and understandings which inform people and which are expressed, reproduced and communicated in partly symbolic form" (Alvesson, 1993, pp. 2-3). The result shows that male have more opportunities than females compared to other females in different countries. In the United States, there is a gender gap in entrepreneurship when starting up a business between male and female entrepreneurs (Gompers \& Wang, 2017). The result shows owning a family business reduces the chance of losing the business, as case six indicated due to the size of the business and its reputation.

Five out of eight male and female entrepreneurs started their business in their middle ages and only three entrepreneurs started their business at a young age with most of them starting their business with the aim of being their own bosses and not controlled by others. Both Saudi men and women entrepreneurs conveyed a prominent predisposition to their activities. It can be demonstrated that case one believes that fear of failure and risk taking could prevent entrepreneurs from starting their business. Becker (1964) asserts that success is viewed as a precursor to failure and failure is anticipated. Furthermore, case one and two believe that one must take a risk before starting any kind of business. In line with Hoskisson et al. (2017), it is important to understand the managerial risk that is being taken and to believe that culture has an influence on entrepreneurial activities, yet three cases do not mention any influence from culture on the creation of their businesses. In 2010, a GEM report found that in the last five years, 9.4 percent of the total workforce in Saudi Arabia started their businesses at the time. It shows that some of the cases have more than one motivational force as well intention behind the creation of their business as Conner \& Armitage (1998) hold that an individual cannot have motivation without the intention.

\subsection{Comparing Between Male and Female Entrepreneurs}

Most male and female entrepreneurs in this paper showed motivation to be their own boss. Conner \& Armitage (1998) claim that individuals cannot have motivation without the intention. It showed that case one was the only entrepreneur who came from an uneducated family compared to the other seven cases. Such has leaded him to run the business to guarantee his future and to support his family. Furthermore, flexibility plays an important role in case one's intention to start up a business compared to the other cases who had other perspectives towards their own intentions. In addition, mamagment is very imoprtant in every business in which weak personality leads to weak management. Nevertheless, the economy is changing as well as the life style of people entering in the process of development since opportunities for male and female entreprenures are greater. In addition, female entrprenures can practice business without limit but for few businesses that require the masculine. Unquestionably, the desire to become your own boss is a demand for male and female but the lack of motivations and the intention behind the business prevents individuals from taking a further step ahead. Individuals must have a target and a plan for the business they want to create as well patience in order to create a successful venture.

Case two also emphasis that knowing the risk and impact of your business is highly important but to him risks management is not important since this business is a continuous process and most people demand for his work. In the worst scenario, case two plans on teaching the law rather than digging deeply in the business. Case three's motivation to joining the business was to learn how to be her own boss since the business had already been established where she needs only to manage the enterprise. She intended to gain experience then start a different type of business with her own money. Inspiration and passion since childhood transformed to an entrepreneurial activity for case four. She was motivated into asking her friends whose parents own businesses for advice, while the other seven cases depended on themselves. Yet she still needed to gain more knowledge in order to start her venture. Acquisition of this knowledge and responsibility came gradually over time because success was between her eyes and she would not accept any failure in her career. Case four is special in that she created a unique business different from those of others.

Above all, comparing all cases to case five's showed an interesting result since there is no intention behind his business. In comparison, cases one and two had different views for their motivation and intentions in starting their own businesses in which case one's main motivation is to be his own boss and case two's motivation is self-efficacy, yet both cases include the motivation of flexibility in working hours.

Furthermore, the possibility and risk of losing ventures is prevalent in all kinds of businesses whether the business is a small or large organization because mistakes are ultimately counted towards the venture and it is 
cumulative over time. Individuals will not notice simple errors accumulating until the business ceases to operate efficiently or face business failures in threatening economic conditions. Likewise, case seven viewed the market as plentiful with opportunities that kept their family business running. History has shown that gender differences are prevalent between women entrepreneurs and men entrepreneurs in which females operate at the micro level at home (Walker \& Brown, 2004). Such is evident in case seven's motivation for starting the business for merely covering her expenses. Another indication about the idea behind case seven's business was achieving self-satisfaction and accomplishment in the most strenuous of obstacles to stand out as a woman in society. Market opportunities in the country are important to utilize the availabilities of business and to efficiently compete with others. Lee (1996) argues that male and female entrepreneurs have great motivations to achieve opportunities, independence, improvement in social status, and engagement within the society.

Very limited attention is given to the motivation and intention of Saudi male and female entrepreneurs, we thus contribute to entrepreneurship literature in that some male entrepreneurs could neither have motivation nor intention but for those who came from a business owning family. A previous study by the commonwealth of Australia (1997) noted that approximately half of ventures established qualify as family business in which more than one shareholder come from the same family. In addition, 40-60 percent of the United States gross national product is produced by family firms (Ward \& Aronoff 1990) while Westhead \& Cowling (1998) report such firms account for over two-thirds of Western developed countries. Most scholars contribute self-efficacy to be a strong factor in business start-ups while in Saudi Arabia being one's own boss has been the cases main motivation. Moreover, Saudi male and female entrepreneurs are similar to western cultures in terms of helping the society and being involved in community.

\section{Conclusions}

The objective of this study was to compare motivation, intention, fear of failure and self-efficacy in starting business ventures in Saudi Arabia. A full description and analysis were given for each entrepreneur's personality and activity. We found the motivation for being one's own boss is significantly different in Riyadh than in Jeddah whereas self-efficacy is greater in Jeddah yet this difference is not significant. Regarding intention, no significant difference was found between region and gender. Finally, both regions consider fear of failure to be predictable. The study presents important contributions to theories and practices in entrepreneurial activities in Saudi Arabia. Our research has contributed to the study in entrepreneurial motivation, intention, role of management, and role of culture of male and female entrepreneurs hence providing more knowledge and information towards the behavior of Saudi entrepreneurs.

\section{References}

Adachi, T., \& Takanori, H. (2017). Gender differences in entrepreneurship and intrapreneurship: an empirical analysis. Small Business Economics, 48(3), 447-486. https://doi.org/10.1007/s11187-016-9793-y

Alvesson, M. (1993). Cultural perspectives on organizations. Cambridge: University Press. https://doi.org/10.1111/j.1467-6486.1993.tb00476.x

Arenius, P., \& Minniti, M. (2005). Perceptual variables and nascent entrepreneurship. Small Business Economics, 24(3), 233-247. https://doi.org/10.1007/s11187-005-1984-x

Audretsch, D. B. (1995). Innovation and industry evolution. Cambridge: Mit Press.

Audretsch, D. B., \& Fritsch, M. (2002). Growth regimes over time and space. Regional Studies, 36(2), 113-124. http://dx.doi.org/10.1080/00343400220121909

Bagheri, A., \& Yazdanpanah, J. (2017). Novice Entrepreneurs' Entrepreneurial Self-efficacy and Passion for Entrepreneurship. Iranian Entrepreneurship (pp. 73-89). Berlin: Springer International Publishing. https://doi.org/10.1007/978-3-319-50639-5_5

Bandura, A. (1977). Self-efficacy: toward a unifying theory of behavioral change. Psychological Review, 84(2), 191. https://doi.org/10.1037/0033-295X.84.2.191

Bandura, A. (1997). Self-efficacy: The exercise of control. New York: Freeman. http://dx.doi.org/10.1037/0033-295X.84.2.191

Barbosa, S. D., Gerhardt, M. W., \& Kickul, J. R. (2007). The role of cognitive style and risk preference on entrepreneurial self-efficacy and entrepreneurial intentions. Journal of Leadership \& Organizational Studies, 13(4), 86-104. http://dx.doi.org/10.1177/10717919070130041001

Baron, R. A. (2004). The cognitive perspective: a valuable tool for answering entrepreneurship's basic "why" questions. Journal of Business Venturing, 19(2), 221-239. https://doi.org/10.1016/S0883-9026(03)00008-9 
Baron, R. A. (2008). The role of affect in the entrepreneurial process. Academy of Management Review, 33(2), 328-340. https://doi.org/10.5465/AMR.2008.31193166

Beck, U. (1992). Risk Society: Towards A New Modernity (Vol. 17). London: Sage.

Becker, W. C. (1964). Consequences of different kinds of parental discipline. Review of Child Development Research, 1(4), 169-208.

Bhave, M. P. (1994). A process model of entrepreneurial venture creation. Journal of Business Venturing, 9(3), 223-242. https://doi.org/10.1016/0883-9026(94)90031-0

Bird, B. (1988). Implementing entrepreneurial ideas: The case for intention. Academy of Management Review, 13(3), 442-453. https://doi.org/10.5465/AMR.1988.4306970

Blanchflower, D. G., Oswald, A., \& Stutzer, A. (2001). Latent entrepreneurship across nations. European Economic Review, 45(4), 680-691. https://doi.org/10.1016/S0014-2921(01)00137-4

Botha, M., \& Robertson, C. L. (2014). Potential entrepreneurs' assessment of opportunities through the rendering of a business plan. South African Journal of Economic and Management Sciences, 17(3), 249-265. https://doi.org/10.4102/sajems.v17i3.524

Boyd, N., \& Vozikis, G. (1994). The influence of self-efficacy on the development of entrepreneurial intentions and actions. Entrepreneurship Theory and Practice, 18(4), 63-77. https://doi.org/10.1177/104225879401800404

Brush, C. G. (1992). Research on women business owners: Past trends, a new perspective and future directions. Entrepreneurship: Theory and Practice, 16(4), 5-31. https://doi.org/10.1177/104225879201600401

Burns, P. (2011). Entrepreneurship and Small Business: Start-up, Growth and Manturity, Houndmills, Basingstoke. London: Palgrave Macmillan. https://doi.org/10.1007/978-0-230-20848-3

Burton, M. D., Sørensen, J. B., \& Dobrev, S. D. (2016). A careers perspective on entrepreneurship. Entrepreneurship Theory and Practice, 40(2), 237-247. https://doi.org/10.1111/etap.12230

Cacciotti, G., \& Hayton, J. C. (2015). Fear and entrepreneurship: A review and research agenda. International Journal of Management Reviews, 17(2), 165-190. https://doi.org/10.1111/ijmr.12052

Carland, J. W., Hoy, F., Boulton, W. R., \& Carland, J. A. C. (1984). Differentiating entrepreneurs from small business owners: A conceptualization. Academy of Management Review, 9(2), 354-359. https://doi.org/10.5465/AMR.1984.4277721

Carree, M., Van Stel, A., Thurik, R., \& Wennekers, S. (2002). Economic development and business ownership: an analysis using data of 23 OECD countries in the period 1976-1996. Small Business Economics, 19(3), 271-290. https://doi.org/10.1023/A:1019604426387

Cavaye, A. L. (1996). Case study research: a multi - faceted research approach for IS. Information Systems Journal, 6(3), 227-242. https://doi.org/10.1111/j.1365-2575.1996.tb00015.x

Chen, G., Gully, S. M., \& Eden, D. (2004). General self-efficacy and self-esteem: Toward theoretical and empirical distinction between correlated self-evaluations. Journal of Organizational Behavior, 25(3), 375-395. https://doi.org/10.1002/job.251

Churchill, C., \& Merry, A. (2017). Transforming Africa through Risk Management: Insurance Matters. Developing Africa's Financial Services: The Importance of High-Impact Entrepreneurship (pp. 61-78). Bingley: Emerald Publishing Limited. https://doi.org/10.1108/978-1-78714-186-520171004

Conner, M., \& Armitage, C. J. (1998). Extending the theory of planned behavior: A review and avenues for further research. Journal of Applied Social Psychology, 28(15), 1429-1464. https://doi.org/10.1111/j.1559-1816.1998.tb01685.x

da Silva, M. A., Gomes, L. F., \& Correia, M. (2009). Cultura e orientação empreendedora: uma pesquisa comparativa entre empreendedores em incubadoras no brasil eeo em Portugal. RAC-Revista de Administração Contemporânea, 13(1).

dos Santos, E. A., \& Silva, C. E. (2012). Os modelos de plano de negócios e sua relevância para sustentabilidade das micro e pequenas empresas. Revista Brasileira de Administração Científica, 3(1), 37-62. https://doi.org/10.6008/ESS2179-684X.2012.001.0003

Eisenhardt, K. M. (1989). Building theories from case study research. Academy of Management Review, 14(4), 532-550. https://doi.org/10.5465/AMR.1989.4308385 
Ferreira, A. D. S. M., Loiola, E., \& Gondim, S. M. G. (2017). Motivations, business planning, and risk management: entrepreneurship among university students. RAI Revista de Administração e Inovação, 14(2), 140-150. https://doi.org/10.1016/j.rai.2017.03.003

Florin, J., Karri, R., \& Rossiter, N. (2007). Fostering entrepreneurial drive in business education: An attitudinal approach. Journal of Management Education, 31(1), 17-42. https://doi.org10.1177/1052562905282023

Foo, M. D. (2011). Emotions and entrepreneurial opportunity evaluation. Entrepreneurship Theory and Practice, 35(2), 375-393. https://doi.org/10.1177/1052562905282023

Gartner, W. B. (1985). A conceptual framework for describing the phenomenon of new venture creation. Academy of Management Review, 10(4), 696-706. https://doi.org/ 10.5465/AMR.1985.4279094

GEM. (2014). Iran: A regional leader in entrepreneurial self-belief. Retrieved from http://www.gemconsortium.org/country-profile/71

Gompers, P. A., \& Wang, S. Q. (2017). Diversity in Innovation (No. w23082). National Bureau of Economic Research. https://doi.org/10.3386/w23082

Greer, M. J., \& Greene, P. G. (2003). Feminist theory and the study of entrepreneurship. New perspectives on women entrepreneurs, pp. 1-24.

Gruber, M. (2007). Uncovering the value of planning in new venture creation: A process and contingency perspective. Journal of Business Venturing, 22(6), 782-807. https://doi.org/10.1016/j.jbusvent.2006.07.001

Hans, V. (2017). Redefining Entreprenuership: Impact on Gender Differences. Retrieved from https://ssrn.com/abstract $=2990457$

Hofstede, G. (1991). Cultures and Organizations: Software of the Mind. London: McGraw-Hill.

Hoskisson, R. E., Chirico, F., Zyung, J., \& Gambeta, E. (2017). Managerial Risk Taking: A Multitheoretical Review and Future Research Agenda. Journal of Management, 43(1), 137-169. https://doi.org/10.1177/0149206316671583

Hsu, D. K., Shinnar, R. S., Powell, B. C., \& Betty, C. S. (2017). Intentions to reenter venture creation: The effect of entrepreneurial experience and organizational climate. International Small Business Journal, 1-21. https://doi.org/10.1177/0266242616686646

Hsu, D. K., Wiklund, J., \& Cotton, R. D. (2017). Success, Failure, and Entrepreneurial Reentry: An Experimental Assessment of the Veracity of Self-Efficacy and Prospect Theory. Entrepreneurship Theory and Practice, 4l(1), 19-47. https://doi.org/10.1111/etap.12166

Kautonen, T., \& Palmroos, J. (2010). The impact of a necessity-based start-up on subsequent entrepreneurial satisfaction. International Entrepreneurship and Management Journal, 6(3), 285-300. https://doi.org/10.1177/001872679304600806

Kelley, D. J., Bosma, N., \& Amoros, J. E. (2010). Global Entrepreneurship Monitor. Babson college: Babson Park, MA and Universidad del Desarrollo. Santiago, Chile.

Kelley, D. J., Brush, C. G., \& Greene, P. G. (2015). The Global Entrepreneurship Monitor Special Report: Women's Entrepreneurship. Boston, MA: Babson College.

Kelley, D., Singer, S., \& Herrington, M. (2016). Global Entrepreneurship Monitor (GEM) 2015/2016 Global Report. Retrieved from http://www.gemconsortium.org/report/49480

Kent, C. A., Sexton, D. L., \& Vesper, K. H. (1982). Encyclopedia of Entrepreneurship. University of Illinois at Urbana-Champaign's Academy for Entrepreneurial Leadership Historical Research Reference in Entrepreneurship. Retrieved from https://ssrn.com/abstract=1496225

Khan, S. A., Tang, J., \& Joshi, K. (2014). Disengagement of Nascent Entrepreneurs from the Start-Up Process. Journal of Small Business Management, 52(1), 39-58.

Kirk, J., \& Belovics, R. (2006). Counseling Would be Entrepreneurs. Journal of Employment Counseling, 43, 50-61. https://doi.org/10.1002/j.2161-1920.2006.tb00006.x

Kolvereid, L. (1996). Prediction of employment status choice intentions. Entrepreneurship: Theory and Practice, 21(1), 47-58. https://doi.org/10.1177/104225879602100104

Krueger, N. (1993). The impact of prior entrepreneurial exposure on perceptions of new venture feasibility and $\begin{array}{lllll}\text { desirability. } & \text { Entrepreneurship }\end{array}$ 
https://doi.org/10.1177/104225879301800101

Krueger, N. F., \& Brazeal, D. V. (1994). Entrepreneurial potential and potential entrepreneurs. Entrepreneurship Theory and Practice, 18, 91-91. https://doi.org/10.1177/104225879401800307

Krueger, N. F., Reilly, M. D., \& Carsrud, A. L. (2000). Competing models of entrepreneurial intentions. Journal of Business Venturing, 15(5), 411-432. https://doi.org/10.1016/S0883-9026(98)00033-0

Kuckertz, A., \& Wagner, M. (2010). The influence of sustainability orientation on entrepreneurial intentions-Investigating the role of business experience. Journal of Business Venturing, 25(5), 524-539. https://doi.org/10.1016/j.jbusvent.2009.09.001

Kumar, R., Singh, S., \& Singh, N. (2012). Successful Women Entrepreneurs in India: Attributes Based Analysis. Asian Journal of Managerial Science, 1(1).

Lee, J. (1996). The motivation of women entrepreneurs in Singapore. Women in Management Review, 11(2), 18-29. https://doi.org/10.1108/09649429610112574

Manolova, T. S., Brush, C. G., Edelman, L. F., \& Shaver, K. G. (2012). One size does not fit all: Entrepreneurial expectancies and growth intentions of US women and men nascent entrepreneurs. Entrepreneurship \& Regional Development, 24(1-2), 7-27. https://doi.org/10.1080/08985626.2012.637344

Manso, G. (2016). Experimentation and the returns to entrepreneurship. Review of Financial Studies, 29(23), 19-2340. http://dx.doi.org/10.1080/08985626.2012.637344

Martin, M. J. (1984). Managing technological innovation and entrepreneurship. Reston Pub. Co.

McClelland, D. C. (1961). The Achieving Society. Princeton, NJ: Van Nostrand. https://doi.org/10.1037/14359-000

McShane, S. L., \& Von Glinow, M. A. (2003). Organizational behavior. New York: McGraw-Hill.

Minniti, M., \& Nardone, C. (2007). Being in someone else's shoes: the role of gender in nascent entrepreneurship. Small Business Economics, 28(2), 223-238. https://doi.org/10.1007/s11187-006-9017-y

Mueller, S. L., \& Goić, S. (2003). East-West differences in entrepreneurial self-efficacy: Implications for entrepreneurship education in transition economies. International Journal for Entrepreneurship Education, 1(4), 613-632.

Mueller, S. L., \& Thomas, A. S. (2001). Culture and entrepreneurial potential: A nine country study of locus of control and innovativeness. Journal of Business Venturing, 16(1), 51-75. https://doi.org/10.1016/S0883-9026(99)00039-7

Piacentini, M. (2013). Women Entrepreneurs in the OECD: Key Evidence and Policy Challenges. OECD Social, Employment and Migration. Working Papers, No. 147, OECD Publishing. http://dx.doi.org/10.1787/1815199X

Reynolds, P. D., Carter, N. M., Gartner, W. B., \& Greene, P. G. (2004). The prevalence of nascent entrepreneurs in the United States: Evidence from the panel study of entrepreneurial dynamics. Small Business Economics, 23(4), 263-284. https://doi.org/10.1023/B:SBEJ.0000032046.59790.45

Rezaei, S., Dana, L. P., \& Ramadani, V. (2017). Introduction to Iranian Entrepreneurship. Iranian Entrepreneurship (pp. 1-11). Berlin: Springer International Publishing. https://doi.org/10.1007/978-3-319-50639-5_1

Ritchie, B., \& Brindley, C. (2005). Cultural determinants of competitiveness within SMEs. Journal of Small Business and Enterprise Development, 12(1), 104-119. https://doi.org/10.1108/14626000510579671

Schneider, K. (2017). Entrepreneurial competencies of women entrepreneurs. Journal of Global Entrepreneurship Research.

Schumpeter, J. A. (1934). Teoria do desenvolvimento econômico: umainvestigac, ão sobre lucros, capital, crédito, juro e o ciclo econômico. In Tradu, cão de Maria Sílvia Possas. Theory of economic development: an investigation of profits, capital, credit, interest and the economic cycle.

Schumpeter, J. A. (2002). Economic theory and entrepreneurial history. Revista Brasileira de Inova, cão, 1(2), 201-224. Retrieved from http://ocs.ige.unicamp.br/ojs/ rbi/article/view/243/157

Shane, S., \& Venkataraman, S. (2007). The promise of entrepreneurship as a field of research. Entrepreneurship (pp. 171-184). Berlin Heidelberg: Springer. https://doi.org/10.1007/978-3-540-48543-8_8 
Shane, S., Kolvereid, L., \& Westhead, P. (1991). An exploratory examination of the reasons leading to new firm formation across country and gender. Journal of Business Venturing, 6(6), 431-446. https://doi.org/10.1016/0883-9026(91)90029-D

Shane, S., Locke, E. A., \& Collins, C. J. (2003). Entrepreneurial motivation. Human Resource Management Review, 13(2), 257-279. https://doi.org/10.1016/0883-9026(91)90029-D

Shook, C. L., Priem, R. L., \& McGee, J. E. (2003). Venture creation and the enterprising individual: A review and synthesis. Journal of Management, 29(3), 379-399. https://doi.org/10.1016/S0149-2063_03_00016-3

Simmons, S. A., Carr, J. C., Hsu, D. K., \& Shu, C. (2016). The regulatory fit of serial entrepreneurship intentions. Applied Psychology: An International Review, 65(3), 603-627. https://doi.org/10.1111/apps.12070

Sivarajah, K., \& Achchuthan, S. (2013). Entrepreneurial intention among undergraduates: Review of literature. European Journal of Business and Management, 5(5), 172-186. Retrieved from https://ssrn.com/abstract $=2447320$

Small Business Research Program (Australia), Australia. Industry Commission, Australie. Department of Industry and Tourism. (1997). A Portrait of Australian Business: Results of the 1995 Business Longitudinal Survey (No. 7-97). Australian Government Publishing Service.

Valencia, F. A. M., Restrepo, I. A. M., \& Restrepo, J. M. V. (2014). Teorías motivacionales en el estudio del emprendimiento [Motivational theories in the study of entrepreneurship]. Pensamiento \& Gestión, 36, 206-238.

Valliere, D., \& Valliere, D. (2017). Multidimensional entrepreneurial intent: an internationally validated measurement approach. International Journal of Entrepreneurial Behavior \& Research, 23(1), 59-77. https://doi.org/10.1108/IJEBR-08-2015-0182

Virtanen, M. (1997). The role of different theories in explaining entrepreneurship. In Entrepreneurship: the engine of global economic development. Journal of Best Papers of the 42nd World Conference, International Council for Small Business.

Wadhwa, V. (2012). Innovation without age limits. Technology Review, 115(2), 66-67.

Walker, E., \& Brown, A. (2004). What success factors are important to small business owners?. International Small Business Journal, 22(6), 577-594. https://doi.org/10.1177/0266242604047411

Ward, J., \& Aronoff, C. (1990). To Sell or Not to Sell. Nation's Business, 78, 63-64.

Welpe, I. M., Spörrle, M., Grichnik, D., Michl, T., \& Audretsch, D. B. (2012). Emotions and opportunities: The interplay of opportunity evaluation, fear, joy, and anger as antecedent of entrepreneurial exploitation. Entrepreneurship Theory and Practice, 36(1), 69-96. https://doi.org/10.1111/j.1540-6520.2011.00481.x

Yin, R. K. (1994). Case Study Research: Design and Methods (2nd ed.). Thousand Oaks, California: Sage Publications.

Yin, R. K. (2013). Case study research: Design and methods. Thousand Oaks, California: Sage publications.

Zhao, H., Seibert, S. E., \& Hills, G. E. (2005). The mediating role of self-efficacy in the development of entrepreneurial intentions. Journal of Applied Psychology, 90(6), 1265. $\mathrm{http}: / / \mathrm{dx}$. doi.org/10.1037/0021-9010.90.6.1265

Zolin, R., \& Watson, J. (2012). Gender and new venture outcomes: not better or worse, just different. In Proceedings of the The Joint ACERE-DIANA International Entrepreneurship Conference.

\section{Copyrights}

Copyright for this article is retained by the author(s), with first publication rights granted to the journal.

This is an open-access article distributed under the terms and conditions of the Creative Commons Attribution license (http://creativecommons.org/licenses/by/4.0/). 